\title{
7. SEDIMENT DEFORMATION AND HYDROGEOLOGY AT THE NANKAI ACCRETIONARY PRISM: SYNTHESIS OF ODP LEG 131 SHIPBOARD RESULTS ${ }^{1}$
}

\author{
Shipboard Scientific Party²
}

\begin{abstract}
The Nankai accretionary prism is arguably the best-known clastic prism in the world. The main objective of ODP Leg 131 was to provide data on the deformational processes and associated hydrogeology of the prism. Such information can be incorporated into the existing geophysical and geological data set to characterize the evolution of sediments in this tectonic setting. The objective was approached by drilling Site 808 , at which the frontal thrust and décollement of the prism toe were penetrated. Drilling also succeeded, for the first time in the history of ocean drilling, in penetrating the complete sedimentary sequence to basaltic basement, and with good core recovery. Both the frontal thrust and the décollement were clearly recognizable in the cored material. Bedding dips, faults, and shear bands analyzed in the cores confirm the pattern of deformation to be mainly due to northwest-southeast shortening. Below the décollement no significant deformation features were observed. Physical properties data show major discontinuities at the décollement, notably an increase in porosity below the décollement. This might indicate excess pore pressure in the subducted section. An increase in porosity below the frontal thrust is less marked and might reflect only the youthfulness of this feature. Attempts to make downhole measurements were severely hampered by unstable hole conditions, but useful constraints have been placed on the thermal regime, some calibration of laboratory physical properties to in-situ conditions has been provided, and in-situ stress and pore pressure were measured in the uppermost sediments. Evidence of channelized fluid flow is inconclusive because no vein structures were observed in the cores, no unequivocal geochemical anomalies indicative of flow were found, and thermal measurements are not significantly different from those predicted by a purely conductive heat-flow model. We conclude that dewatering probably occurs mainly through diffuse flow at this site.
\end{abstract}

\section{INTRODUCTION}

The accretion of sediments in ocean trenches is an initial step in the process of mountain building and continental crustal growth. An understanding of the processes operating during accretion is thus of fundamental importance. These processes are an attractive target for drilling that allows both recovery of samples from depth, and in-situ measurements of physical parameters. At present, technical limitations restrict complete drilling penetration of a prism to the relatively thin sediments near the prism toe. The landward increase in complexity of the structures and processes also argues for initial concentration on the relative simplicity of the prism toe.

There are three essential aspects that must be investigated. First, there should be a mechanical model that relates the geological structures to the stress fields producing them, and to the physical properties of the deforming sediments. Second, a hydrological model should relate the compaction and dewatering of the sediment to the flow patterns constrained by bulk permeability or channeled flow. Finally, a geochemical model should relate the diagenetic changes in the sediments to pore-water interaction and the thermal regime. These three models are heavily interdependent and must be developed within an interdisciplinary program.

Leg 110 investigated a clay-dominated prism, while in contrast Leg 131 targeted a clastic-dominated prism. The Nankai Trough was considered one of the best places to target a clastic prism because (1) substantial site survey data exist, including excellent images of the thrust structures by seismic profiling (Nasu et al., 1982; Aoki et al., 1982; Kato et al., 1983; Moore et al., 1990); (2) the décollement (detachment zone) is

\footnotetext{
1 Taira, A., Hill, 1., Firth, J., et al., 1991. Proc. ODP, Init. Repts., 131: College Station, TX (Ocean Drilling Program).

2 Shipboard Scientific Party is as given in the list of participants preceding the contents.
}

relatively shallow (ca. $1000 \mathrm{~m}$ ) and can be penetrated with present drilling technology; (3) the trench sediments are sandy turbidites that are typical of most ancient accretionary prisms (e.g., Shimanto Belt, Taira et al., 1988a, 1988b; Southern Upland, Leggett et al., 1982); (4) large heat flow in the trough indicates a steep thermal gradient and extensive diagenetic alteration; and (5) an almost direct ancient analog is exposed on land (the Shimanto accretionary prism), providing an opportunity for comparative study.

This paper summarizes the data obtained on Leg 131 and discusses the implications for the development of models of prism processes. The regional tectonic structure is reviewed, the scientific results of the shipboard measurements are described, and the relationship of the specific structures encountered at Site 808 to this regional setting are explained. Our discussion centers around the relevance of these new data to the processes indicated above.

\section{BACKGROUND}

\section{Tectonic Setting of the Nankai Trough}

The arc-trench system of southwest Japan shows unique characteristics that can be summarized as follows (see summary by Shiono, 1988; Niitsuma, 1988; and Taira et al., 1989): $\mathrm{km}$.

1. The Wadati-Benioff Zone extends only to a depth of 50

2. Volcanic activity has been scarce since middle Miocene.

3. There is anomalously large heat flow within the forearc region.

4. The trench (Nankai Trough) is shallow and rarely exceeds $4900 \mathrm{~m}$.

5. The entire arc basement and forearc region are composed of accreted material.

The first three characteristics are closely related to the age and history of the subducted oceanic lithosphere, that of the 
young, backarc Shikoku Basin. The fourth and fifth characteristics reflect the history of sediment input and accretion at the trench. To understand these characteristics of the Southwest Japan arc-trench system and the tectonic setting of the Nankai Trough, it is necessary to review the geologic development of the arc.

The Japanese island arcs comprise five segments of the major arc systems of the western Pacific: Kuril, northeast Japan, southwest Japan, Ryukyu, and Izu-Bonin (Izu-Ogasawara) arcs (Fig. 1 from Geological Background and Objectives chapter). Two separate oceanic lithospheric plates, the Pacific Plate and the Philippine Sea Plate, are being subducted at these arcs. The junction of the northeast Japan, southwest Japan, and Izu-Bonin arcs is a consequence of arc-arc collision producing a TTT triple junction. This complex arc-trench architecture is a product of dramatic Neogene tectonic evolution. However, the basement geology of the islands can be traced back to the late Paleozoic.

The geology of the Japanese islands can be broadly classified into three categories: Neogene cover sequence, igneous intrusives, extrusives of mostly Mesozoic and Cenozoic age, and basement rocks. Of these, only the basement rocks are considered here. The basement rocks mostly comprise a late Paleozoic to Cenozoic accretionary complex that shows various degrees of metamorphism. These basement rocks are best exposed in southwest Japan, where they display a long history of sediment accretion processes (Fig. 3 from Geological Background and Objectives chapter). The late Paleozoic and Jurassic prisms are mostly composed of thrust piles of mélange and relatively coherent turbidite sequences. The mélange lithology includes various-sized tectonic slivers of the uppermost part of the oceanic crust (pillow lavas), seamount complex (pillow lavas and reef limestone), pelagic sequence (bedded radiolarian cherts and pelagic shale), and hemipelagic sequence, embedded in a scaly argillaceous matrix (Taira et al., 1989).

The youngest accretionary prism, which was formed at the continental margin of eastern Asia before the opening of the Japan Sea, is called the Shimanto Belt. This is also composed of thrust piles of turbidite sequence and mélange (Taira et al., 1988a). The age of the Shimanto Belt ranges from Cretaceous to early Miocene, the younger part being exposed more to the Pacific side of southwest Japan and shows a record of successive accretion toward the present trench. The Shimanto Belt has been interpreted as offscraped packages of trench turbidites, bounded by mélange belts that contain tectonic slivers of oceanic plate materials in a scaly argillaceous matrix.

Formation of the Shimanto Belt overlapped the start of the opening of the Shikoku Basin but preceded the opening of the Sea of Japan, which more or less shaped the present configuration of the island arc systems of the Japanese islands. The Shikoku Basin was formed as a backarc basin of the Izu-Bonin arc primarily by east-west spreading ( 25 to $15 \mathrm{Ma}$ ), possibly followed later (14 to $12 \mathrm{Ma}$ ) by more north-south trending spreading. The basement topography in the central part of the Shikoku Basin shows a north northwest-south southeasttrending topographic high and a chain of seamounts that runs approximately parallel to the magnetic anomalies. The central topographic high has been interpreted as a fossil spreading center, and the magnetic anomalies as well as previous drilling results indicate a spreading episode of Oligocene-Miocene age ( 25 to 15 Ma; Kobayashi and Nakada, 1978; Shih, 1980). A new interpretation of basement topography and magnetic anomalies obtained during the Kaiko Project (Kaiko I Research Group, 1986) showed a north-south trending spreading axis, active during the final stage of opening in the central region and producing a complex topographic mixture of north-south trending transform faults and northwest-southeast trending horst-graben features. This interpretation of magnetic anomalies assigned the age of the youngest part of the Shikoku Basin to be 14 to $12 \mathrm{Ma}$; Chamot-Rooke et al., 1987). Subsequent subduction of the Shikoku Basin and collision of the Izu-Bonin arc have since controlled the history of tectonics and sedimentation in the southwest Japan arc (Niitsuma, 1988; Okuda and Honza, 1988).

In the newly formed Shikoku Basin, fine-grained terrigenous sediments, volcanic ash and biogenic components started to accumulate as hemipelagic sediment cover. The collision of the Bonin arc against the southwest and northeast Japan arcs (called the Izu collision zone) produced major crustal imbrication. The topographic manifestation of this tectonic activity is the uplift of the central mountain range of Honshu (Japan Alps), which provided the main provenance of clastic sediments to the Nankai Trough. An enormous yield of eroded clastics produced a fan-delta system at the collision boundary. Earthquakes have periodically destabilized the fan-delta slope to create turbidity currents that flowed westward along the Nankai Trough axis. A sequence of hemipelagite and turbidite sediments has been deformed and offscraped to form an accretionary prism with typical fold-thrust belt geometry.

\section{Morpho-tectonic Features of the Nankai Trough}

The topography and tectonic regime of the Nankai Trough forearc and trench floor varies considerably along strike (Fig. 2, from Geological Background and Objectives chapter). The eastern end of Nankai Trough and its extension, the Suruga Trough, are dominated by the tectonics of the Izu collision zone. A steep gradient of both oceanic and landward slopes, oblique convergence, and considerable erosion of slope and trough floor are morpho-tectonic characteristics of this region (Shimamura, 1988).

Toward the west the trough floor becomes flat and a systematic pattern of step-like topography, apparently related to the thrust-fold geometry of the accretionary prism, develops along the lower part of the landward slope. The western end of the Nankai Trough is another collision/subduction boundary, where the Kyushu-Palau Ridge subducts underneath Kyushu Island. Because of the much subdued topography of the ridge, the compressional tectonic effects here are less profound than in the Izu collision zone and no evidence of large-scale crustal imbrication has been documented.

The structure of the toe of the Nankai Trough accretionary prism in the central and western Nankai Trough, approximately $137^{\circ} \mathrm{E}$ longitude, is characterized by two structural zones; the protothrust zone and the imbricate thrust zone. The protothrust zone designates an initial deformation feature observed both on the bathymetric map and seismic profiles. This zone is characterized by a development of small vertical displacement ( 5 to $20 \mathrm{~m}$ ) faults, gentle seaward tilting of the trench wedge, and gradual thickening of the sedimentary section. The protothrust zone is followed, to the landward, by development of a major thrust (frontal thrust), usually with vertical displacement of 50 to $200 \mathrm{~m}$, which marks an initiation of the imbricate thrust zone. In most of the seismic sections, the first two or three thrusts can be imaged by a reflection and are accompanied by a hanging-wall anticline. The thrusts sole to a horizontal reflector in the deeper part of the section. Judging from its structural style, this horizontal reflector that develops in the middle of the hemipelagic section can be interpreted as a décollement (detachment surface). The reflected seismic wavelet is of reverse polarity and a lowvelocity zone beneath it has been observed (Aoki et al., 1986). Toward the arc, the clear seismic image within the accretion- 
ary prism is lost and replaced by vague, landward-dipping reflectors. It is notable, however, that a strong bottomsimulating reflector (BSR) develops slightly landward of the frontal thrust. This BSR has been interpreted as the base of the gas hydrate stability field, which is an indicator of regional heat flow and possibly fluid flow. Farther landward, the accretionary prism is covered by a series of slope basins, which are gradually tilted landward and eventually are folded into synclinorium form.

Although there is a gross uniformity in structural styles of the central and western Nankai accretionary prism as explained above, there are noticeable local variations. The Leg 131 region shows the following unique features that are important in understanding the structural and hydrogeological characteristics of this region:

1. The lowest critical taper angle in the Nankai accretionary prism.

2. The longest seismically traceable décollement.

3. The highest regional heat flow.

4. One of the thinnest sedimentary sections.

5 . One of the areas where spacing regularity and strike direction continuity of thrusts and folds are well documented (Figs. 4 and 5 from Geological Background and Objectives chapter).

6. Oceanic basement near the site is flat, and no major disturbances are evident from seismic profiles.

For the study of hydrogeology and structural evolution, this site offered an ideal place because we expected higher temperature, elevated fluid pressure, and relatively simple structural style. We hoped that the various parameters to be measured should show a large gradient that would be easily detected.

Seismic line NT62-8 (backpocket Fig. 2 from Structural Framework chapter, this volume) provides a basic stratigraphic and structural framework for the drilling site, being complemented by many other regional seismic lines including ones obtained by Ocean Research Institute, University of Tokyo and JAPEX. The profile NT62-8 and a $3.5-\mathrm{kHz}$ record obtained during the underway geophysical site survey show that in the drilling area the trough is $14 \mathrm{~km}$ wide with a flat seafloor and a possible shallow channel feature in the middle. At about $7 \mathrm{~km}$ landward of the outer margin of the trench fill, the trench floor is elevated by $10 \mathrm{~m}$ or so, indicating the seaward extent of tectonic thickening. At the same location, in the middle of the hemipelagic section (950 mbsp), a reflector can be traced landward to what becomes the décollement. Landward of the horizontally-bedded trench fill, the trench turbidite reflectors are tilted seaward and the first indication of major faulting can be recognized at CDP 820. An anticline of about $1.5-\mathrm{km}$ wavelength is imaged, the landward edge of which is bounded by the frontal thrust with $150 \mathrm{~m}$ vertical displacement. We define the frontal thrust as the boundary between the protothrust zone and the imbricate thrust zone. Behind this anticline, a second major thrust can be defined as a reflector dipping about 20 degrees in the upper part and more steeply in the deeper part of the section. These faults all sole out to the décollement that occurs at 970 mbsf below the toe of the prism (about CMP 950 on seismic line NT62-8).

Site 808, the single site of Leg 131, comprised seven closely spaced holes. Holes $808 \mathrm{~A}, 808 \mathrm{~B}$, and $808 \mathrm{C}$ were dedicated to coring, whereas the remainder were primarily for downhole measurements and wireline logging. All the holes are within a $150 \mathrm{~m} \times 300 \mathrm{~m}$ area and are located toward the oceanward rim of the first hanging-wall anticline above the frontal thrust.
Hole $808 \mathrm{C}$ at 1327 mbsf is the deepest penetration hole ever drilled into an accretionary prism.

\section{SCIENTIFIC RESULTS}

\section{Lithology and Stratigraphy}

The lithologies encountered at Site 808 have been divided into five lithologic units mainly based on grain size, bed/layer thickness, sedimentary structures, and mineralogy as shown in Table 2 (Sedimentology Section, Site 808 chapter, this volume).

Unit $\mathrm{I}$ is about $20 \mathrm{~m}$ thick, representing deposits of the trench landward slope apron, comprising mainly fine-grained turbidites and slump deposits. Some of the thin, sandy turbidites may have been deposited by axial flows that lapped onto the lower slope as plumes of suspended sediment. The slump deposits are characterized by repeated occurrence of recumbent folds, bed truncation, and pinch-and-swell features.

Unit II represents the main episode of trench infilling by turbidites. The Unit is divided into three subunits that show an overall coarsening upward trend. Subunit IIa is $100 \mathrm{~m}$ thick and composed of thick beds (up to $3 \mathrm{~m}$ thick) of very coarse to medium-grained sand showing graded beds, scoured bases, and concentrations of plant debris at the tops. This unit is interpreted as axial trench sandy deposits. Subunit IIb is 144 $\mathrm{m}$ thick and much finer grained than Subunit IIa. The dominant lithology is 10 - to $50-\mathrm{cm}$ thick turbidite beds composed of fine-grained sand at the base with parallel lamination, ripple lamination, and bioturbated silt to thin hemipelagic mud. Subunit IIc, $147 \mathrm{~m}$ thick, is characterized by very fine-grained sand and silt-sized thin turbidite layers intercalated with hemipelagic mud. The Subunits IIb and IIc are inferred to represent outer depositional sites of the axial trench environment.

Unit III is $62 \mathrm{~m}$ thick and shows intercalations of three different types of lithology: thin graded silt, highly bioturbated hemipelagic mud, and volcanic ash layers. Because this unit shows characteristics of both overlying Subunit IIc (silt turbidite) and Subunit IVa (hemipelagite and ash layers), the unit represents a transitional zone such as the trenchward slope of the outer swell of the oceanic plate.

Unit IV is dominated by a rather monotonous sequence of bioturbated olive-gray hemipelagic mudstone that is divided into two subunits mainly based on the abundance of ash-layer intercalations. The volcanic ashes are much more common in Subunit IVa than IVb.

Unit V shows a unique lithology: thick white acidic tuffs interbedded with varicolored (greenish gray, buff red, and dark olive gray) hemipelagic mudstone, the total thickness of which is $46 \mathrm{~m}$. The maximum thickness of an individual acidic tuff bed reaches $4.5 \mathrm{~m}$; this bed also shows altered glass shards.

Unit VI represents basalts and intercalated red tuffaceous mudstones. The uppermost unit of the basalts is inferred to be a sill intruded into sediments, and the lower part is inferred to be pillow lavas.

\section{Mineralogy and Diagenesis}

Thin-section examination of turbidite sands shows a variety of components including quartz, feldspar, volcanic rock fragments, sedimentary rock fragments, chert, and metamorphic (generally low-grade) rock fragments and several suites of heavy minerals, typically pyroxene, amphibole, and mica. The provenance must be from a polymictic province. The data agree well with Taira and Niitsuma's (1986) tabulation and support their inference on the Suruga Trough-Fuji River 
drainage source (Fig. 48, Sedimentary Petrology section, Site 808 chapter).

The bulk mineralogy determined by XRD analysis indicates the relative proportions of the major crystalline components of the sediments: quartz, feldspar, clay minerals, and calcite. Other minor components include several species of heavy minerals and zeolites.

There is a general increase in quartz content and decrease in feldspar content downward. As there is a rough correlation between quartz/feldspar ratio and grain size, this down-section trend indicates a general decrease in grain size (Fig. 32E in Sedimentary Petrology section, Site 808 chapter).

The calcium carbonate content of the sedimentary section (Fig. 32D in Sedimentary Petrology section, Site 808 chapter) is primarily controlled by the calcareous fossil content. Sporadic occurrence of very high values $(30 \%)$ occur where sediments are light olive-gray, nannoplankton-rich/micritic oozes that probably represent events of calcareous turbidity current deposition. Discarding these high values, the pattern of $\mathrm{CaCO}_{3}$ content shows three maximums: a broad peak from $600 \mathrm{mbsf}$ to $850 \mathrm{mbsf}$, a sharp peak at $970 \mathrm{mbsf}$, and another peak at 1150 mbsf. The first $600-850$ mbsf-peak coincides with the upper Shikoku Basin hemipelagite, and smear-slide investigation shows an increase in nannoplankton and foraminifer content. The second peak matches roughly with the décollement; the maximum occurs from within the zone of deformation to $20 \mathrm{~m}$ into the undeformed section below. The origin of this $\mathrm{CaCO}_{3}$ content is not clear as there is no visible increase in biogenic component. There is a possibility that this peak of $\mathrm{CaCO}_{3}$ content may reflect diagenetic precipitation. The third peak seems to be related to another interval of increased biogenic contribution.

Clay minerals include illite, chlorite, smectite, and kaolinite in the order of relative abundance. These clay minerals were supplied by diverse detrital sources, as suggested previously by Chamley et al. (1986). The abundance of these minerals relative to total bulk does not change significantly with depth; however, there are subtle changes within the clays that are important (Figs. 36, 38, 44, 45, 46, and 47 in Sedimentary Petrology section, Site 808 chapter). Observations of core lithologies indicate that volcanic input increases in the lower part of the sedimentary section relative to the upper sandy units. However, the data show a small decrease in smectite content. It is noteworthy that the peak associated with the (001) illite reflection becomes increasingly broad and asymmetric beginning at a depth of roughly 530 mbsf. These lines of evidence indicate that possible diagenetic alteration of smectite to illite-smectite mixed layer phase may have taken place below about 530 mbsf. Additional detailed work must be carried out, however, before we can make further inferences concerning these important processes.

Another aspect of diagenetic alteration detected was the discrete occurrence of zeolites. Zeolites, mainly clinoptilolite, occur in greatest abundance from 740 to $816 \mathrm{mbsf}$, which matches with the lower part of ash-rich Subunit IVa (Fig. 34 in Sedimentary Petrology section, Site 808 chapter).

\section{Biostratigraphy and Magnetostratigraphy}

The age assignment of the stratigraphic section recovered at Site 808 was achieved mainly by two methods: calcareous nannoplankton biostratigraphy and magnetostratigraphy. Nannoplankton occur throughout the section despite the near lysoclinal depth of deposition. Preservation was moderate to poor, but was adequate for reasonable age control.

The results of paleomagnetic measurements show good agreement with biostratigraphy. The intensity of magnetization is generally strong compared with normal marine sedi- ments. The magnetization is stable, but the intensity declines considerably between 700 to 800 mbsf. Shipboard examination of magnetic properties of discrete core specimens from this interval suggests the possibility of rather strong remagnetization imprints at that interval. By discarding parts of the interval with very weak intensity, we established reasonably well-constrained magnetostratigraphy throughout the section.

Figure 76 (see Paleomagnetics section, Site 808 chapter) shows the established stratigraphy and age assignment, and Figure 160 (see Sedimentation Accumulation Rates, Site 808 chapter) shows rate of sedimentation. The age of the base of lithologic Unit III, which shows the influence of the trench turbidity current activity, is about $0.46 \mathrm{Ma}$. The Shikoku Basin hemipelagic sedimentation ranges from 0.46 to $15 \mathrm{Ma}$. The rate of trench sedimentation reaches almost $1400 \mathrm{~m} / \mathrm{m}$.y. The Shikoku Basin hemipelagic sequence, Unit IV, shows three separate sedimentation rates. From $1240 \mathrm{mbsf}$ to 1090 mbsf, the sedimentation rate averages $100 \mathrm{~m} / \mathrm{m}$.y., then it drops to $35 \mathrm{~m} / \mathrm{m} . \mathrm{y}$. between $1090 \mathrm{mbsf}$ to $980 \mathrm{mbsf}$. It increases to $200 \mathrm{~m} / \mathrm{m}$.y. at $620 \mathrm{mbsf}$ and upward. The sedimentation rate of the hemipelagic mud estimated from various piston coring results in the landward slope basins and forearc basins in this region is about 200 to $300 \mathrm{~m} / \mathrm{m}$.y., comparable to the upper part of Subunits IVb and IVa. It is noteworthy that a break in the sedimentation rate at $980 \mathrm{~m}$ occurs just below the horizon of décollement development.

\section{Correlation with Seismic Units}

Depth migration of seismic line NT62-8 provided an excellent image in depth because of velocity control provided by a previous two-ship experiment (Stoffa et al., in press). Thus, there is a good correlation between the lithologic units based on core description and the major seismic units defined in the profile (backpocket Fig. 155 in Seismic Stratigraphy and VSP section, Site 808 chapter). The upper part of the axial sandy trench deposits, Subunits IIa and IIb, are represented by a series of laterally continuous, mediumamplitude reflections. The outer marginal trench deposits (Subunit IIc) are a zone of low-amplitude reflections imaged above and below the frontal thrust. The trench-to-basin transition (Unit III) is represented by a series of four moderate- to high-amplitude reflections that are continuous laterally to the southeast below the trench wedge. The upper $60 \mathrm{~m}$ of the upper Shikoku Basin hemipelagites (upper part of Subunit IVa) are acoustically nonreflective. The lower part of Subunit IVa is imaged as a series of three moderateamplitude, laterally continuous reflections. The upper part (above the décollement) of the lower Shikoku Basin hemipelagites (Subunit IVb) is characterized by low- amplitude, discontinuous reflections. Below the décollement, Subunit $\mathrm{IVb}$ is almost acoustically nonreflective; this zone has several very low-amplitude, highly continuous reflections. The acidic volcaniclastic deposits (Unit V) are represented by a single moderate-amplitude reflection overlying the very high- amplitude, laterally continuous, low-frequency basement reflection (Unit VI).

\section{Structural Geology}

Leg 131 produced probably the largest structural data set in the history of DSDP-ODP Legs. This includes 3000 structural measurements, over $70 \%$ of which have been corrected to geographic coordinates using paleomagnetic data.

The structural features observed at Site 808 were classified into four main types: small faults, shear bands, zones of breccia/scaly fabrics, and steepened beds (Fig. 59 in Structural Geology section, Site 808 chapter). The macroscopic- 
scale character and distribution of these structures with depth are described in the following paragraphs.

Small faults, which are the most abundant features in the cores, typically occur as narrow $(<1 \mathrm{~mm})$, sharply bounded zones of small displacement (less than a few centimeters) that appear much darker than the surrounding sediments. The fault surface is commonly coated with dark gray material, which XRD-analysis indicated to be rich in iron-sulfate minerals (greigite/pyrite). The surfaces show slickenlines and various degrees of polished appearance.

Shear bands appear macroscopically as diffusely bounded zones that are slightly darker than the surrounding material. The bands are commonly a few millimeters across, but some examples reach a width of $1 \mathrm{~cm}$. Although the bands show some displacement, the displacements are relatively small $(<$ a few $\mathrm{mm}$ ) compared with small faults, even when the bands are very wide and appear well developed. The surface grooves and polish are not as well developed as in the faults. In three dimensions, the bands appear to form relatively simple conjugate sets centered on bedding, with a dihedral angle ranging from 30 to 45 degrees.

The zones of breccia and scaly fabrics are marked by a high concentration of trapezoidal and lens-shaped fragments of mudstone with highly polished and/or slickensided surfaces. Steepened bedding dips occur in several horizons including overturned bedding in the frontal thrust zone.

Measurements of these structural features throughout the core enabled six structural domains to be distinguished (Fig. 50 in Structural Geology section, Site 808 chapter). Domain 1 represents the shallowest structural level. The upper part of the domain, above 200 mbsf, shows syndepositional deformation features including a $10-\mathrm{m}$ thick slump horizon, and below 260 mbsf tectonic structures become increasingly abundant. Domain 2 includes the interval of intense deformation that constitutes the frontal thrust. The zone is defined by steepened and overturned bedding dips, faulting, and the development of fine breccias and scaly fabrics. Domain 3 occurs between the frontal thrust and décollement and is composed of moderately to intensively deformed trench deposits to hemipelagic mudstone of the Shikoku Basin (Units II to IV). The deformation is characterized by arrays of the macro-scale deformation features mentioned above, showing a markedly heterogeneous distribution. Domain 4 includes the interval of intense faulting and brecciation associated with the décollement. This interval lies within the hemipelagic sediments of the Lower Shikoku Basin and is about $19 \mathrm{~m}$ thick. Domain 5 represents the hemipelagic sediments of Unit IV that are being underthrust beneath the décollement and the Nankai accretionary prism. Deformation structures are conspicuously feeble in their development. Domain 6 comprises the fractured and veined basalts of the oceanic basement.

In general, most of the structures strike northeast/southwest, parallel to the trend of the Nankai Trough, when paleomagnetically corrected for rotations due to drilling. Rotated slickenlines and conjugate shear bands and faults also suggest that the shortening direction associated with these structures trends northwest, parallel to the inferred plate convergence vector. There are a few exceptions to this generalization that will be discussed below. We discuss now the features of the three most important structural domains in more detail: the frontal thrust, deformed sediments between thrust and décollement, and the décollement itself.

\section{Frontal Thrust Zone}

This zone corresponds to structural domain 2 and contains the highest concentration of steeply dipping beds. Within this zone, bedding increases in dip up to 90 degrees and becomes overturned. The observed bedding orientations closely constrain the style and orientation of the overall structure within the thrust zone, even though the core recovery was relatively poor in the upper part of this zone. When corrected paleomagnetically for rotations due to drilling, the bedding planes dominantly face toward the southeast, suggesting the presence of inclined folds with axial surfaces dipping toward the northwest (Fig. 63 in Structural Geology section, Site 808 chapter).

The shear bands and faults range in abundance between 5 and 20 per meter, with localized zones having 20 faults/shear bands per meter. In general, these structures strike to the northeast-southwest when corrected with paleomagnetic data (Fig. 65 in Structural Geology section, Site 808 chapter). The breccia/scaly fabrics are best developed at about $366 \mathrm{mbsf}$.

The frontal thrust of the prism is regarded as a zone that extends in Hole $808 \mathrm{C}$ from 360 down to 390 mbsf, based on the distribution of scaly breccias and frequency of faults and shear bands. The displacement associated with the thrust zone is best marked by a mudstone-pebble conglomerate horizon, the top of which is recognized at both 264.4 mbsf in Hole $808 \mathrm{~B}$ and at 409.1 mbsf in Hole $808 \mathrm{C}$. The observed vertical difference between these two levels, the stratigraphic throw of the thrust, is therefore about $145 \mathrm{~m}$, and, using a $30^{\circ}$ dip for the structure, the fault-parallel separation is $309 \mathrm{~m}$. This last value also represents the true total movement within the thrust zone, assuming the motion is dip-slip, as suggested by slickenline orientation.

\section{Deformed Sediments between the Thrust and Décollement}

The sediments between the frontal thrust and the décollement record the initial deformation of the lower part of the accretionary prism. It is characterized by an overall decrease in the development of shear bands with depth, a generally low bedding dip ( $<10$ degrees), and the presence of faults throughout the zone but with intervals of marked concentration (Fig. 59 in Structural Geology section, Site 808 chapter).

The shear bands are concentrated in the 200 -m interval between just above the frontal thrust (above 300-350 mbsf) and 550 mbsf, where there are on average over 10 bands per meter. Below about 560 mbsf the shear bands are very rare. The distribution of the shear bands seems to be controlled by two factors: appropriate strain magnitude and pre-existing fabric. The deformation associated with the frontal thrust provided the necessary strain that affected lithologies that bore the necessary fabric.

The orientation of small faults changes down the section (Figs. 65, 66, 67, 69, 71, and 72 in Structural Geology section, Site 808 chapter). Above $600 \mathrm{~m}$, the faults are generally conjugate, as are shear bands. Between 600 to 720 $\mathrm{m}$ the faults show a more complex pattern of orientation; generally with low dip angles but with variable dip directions. The slickenlines, however, consistently show a northwest-southeast movement direction. Between 780-820 mbsf there are apparently two sets of fault orientations; one similar to the $600-720-\mathrm{m}$ interval and the other consisting of high-angle faults with down-dip and strike-slip offset. The latter predates the former set and seems to represent an early phase of faulting, judging from the paucity of open fractures. Between 880-930 mbsf, further complexity occurs. This zone marks the highest concentration of faults, where in addition to the fault types described above, a peculiar set of faults is recorded. This set shows slickenlines trending east-northeast, parallel to the Nankai Trough, and at 90 degrees to the shortening direction inferred for the accreted sediments at higher structural levels. The reason for this is unclear and requires further investigation. 
An isolated, centimeter-wide sandstone dike occurs at 813 mbsf. It is composed of medium-grained sandstone injected into a dark gray silty claystone host rock. The dike dips moderately to the northwest approximately parallel to several faults that are also present in this area. This feature represents the only direct evidence observed in the cores for overpressuring anywhere within the prism. Considering the low probability of encountering a single dike by drilling, it is possible that such features are quite abundant.

\section{The Décollement}

Domain 4 represents the basal décollement of the Nankai accretionary prism. It contains a relatively high concentration of faults per meter and a local increase in bedding dip and marked brecciation. The top of the domain is sharply bounded, marked by the abrupt onset of a well-developed, $1.5-\mathrm{m}$ thick, breccia/scaly fabric zone at about $945 \mathrm{mbsf}$, and a sharp increase in the number of faults per meter. The bottom of the domain at 964.3 mbsf is also very sharp and is marked by both an abrupt decrease in brecciation and by a rapid drop in the number of faults per meter. We therefore consider this domain to be about $19 \mathrm{~m}$ thick. There is a $10-\mathrm{cm}$ thick, very clay-rich horizon at the sole of the décollement. Whether this clayey horizon is the original décollement sole or a drillinginduced artifact was not resolved by core observation or shipboard XRD analysis.

Within this interval of intense faulting and brecciation we were able to locate a $1-2-m$ section that was both magnetically and structurally coherent. This zone was carefully dissected for fault orientation and kinematic indicators to compare it with the sections above and below the décollement. The faults in this interval generally dip to the northwest and have slickenlines that trend northwest-southeast, consistent with the direction of plate convergence direction in this area (Fig. 71 , Structural Geology section, Site 808 chapter). There are no prominent veins or mineral precipitates suggestive of abundant fluid flow in the décollement. However, this does not preclude the possibility of fluid flow activity. This point will be discussed later.

In summary, structural analysis provided a measure of the strain recorded in the accreted sediments above the décollement. This suggests consistent northwest-southeast shortening that is parallel to the convergence direction. On the other hand, below the décollement, there is no evidence for such strain, and deformation structures are very sparse. Because the contrast occurs over no more than a few meters, the stress boundary must be very sharp.

\section{Physical Properties}

The physical properties of the sediments in the accretionary prism are a function both of their original depositional history and of later mechanical and chemical diagenetic processes. For this reason they have great potential for revealing details of the accretion processes. Similar data from the sediments seaward of the deformation front would facilitate the separation of the depositional and accretion effects. Because directly comparative data are not available, care must be taken to attempt to separate these two factors, namely the physical characterization of lithologic units and the estimation of tectonically generated components of compaction and strength changes of the sediment.

The physical properties data at Site 808 were collected at a mean sample spacing of about $1 \mathrm{~m}$. The spacing variability is, however, high. Sampling was restricted in the upper part of the section, above $300 \mathrm{mbsf}$, where the recovery was poor and the cores were badly disrupted by gas expansion. Below this, core recovery was generally good except in specific zones, which unfortunately coincide with critical structures such as the décollement. Measurements were obtained primarily from Hole $808 \mathrm{C}$, which was cored through the interval from 300 to 1290 mbsf in sediments. The upper $350 \mathrm{~m}$ of the sequence was cored in Holes $808 \mathrm{~A}$ and $808 \mathrm{~B}$. In the following discussion the data have been assembled into one continuous array with depth. The index properties (bulk density, porosity, water content, and grain density) coupled with measurements of seismic velocity provide the essential basis for analysis of the physical properties (Figs. 116 and 121 in Physical Properties section, Site 808 chapter).

The most striking features of the physical properties record are a dramatic downhole decrease in bulk density and velocity and an increase in porosity that occur at a depth of about 960 mbsf. When viewed in detail a zone can be discerned where the bulk density increases sharply by about $0.1 \mathrm{~g} / \mathrm{cm}^{3}$ at 950 mbsf, then decreases equally sharply by about $0.25 \mathrm{~g} / \mathrm{cm}^{3}$ at 965 mbsf. This zone is the décollement as identified by the structural fabric of the cores. Both above and below the décollement the physical properties of the sediment show a normal compaction trend with depth, this being offset sharply across the décollement. The lithology is uniform across this whole zone, making it clear that the effect seen here is tectonic. From comparison with the porosity-depth function of Shikoku Basin deposits from Site 582 (Bray and Karig, 1986), it appears most likely that the sediments under the décollement are undercompacted. This in turn suggests restricted dewatering of the subducted sediments and associated elevated pore pressures. The décollement may act as a barrier to upward flow, either by being impermeable or by being overpressured itself.

Above about 800 mbsf the scatter in the physical properties data is greater so that the underlying trends are not so clearly displayed. This scatter results from the increased lithological diversity on a fine scale through the Upper Shikoku Basin hemipelagic and ash/tuff deposits (Unit IV) and the transitional and trench wedge turbidite deposits (Units III and II). The variation in grain density clearly documents the lithologic variability. Above 300 mbsf the data points are very scattered.

Just above 400 mbsf a less distinct offset in the density and velocity data has a similar pattern to that seen at the décollement. This change is the signature of the frontal thrust fault. Here it can be seen that the sediment in the footwall of the thrust has not responded to the increased lithostatic load created by the fault displacement. This may be interpreted as indicating either delayed dewatering, or the very recent nature of the thrust event.

Between the thrust and the décollement the physical properties trends are smoothly variable. These variations clearly reflect the lithologic changes, but it is not clear how much of this is primary lithologic effect, and how much may be differing tectonic response in the different lithologies.

Acoustic velocity data generally follow the trend shown by the density values. A detailed acoustic impedance log can be calculated from the sample data and shows a good qualitative correlation with the seismic reflection data across this site. It is interesting to note that the acoustic anisotropy shows a trend of decreasing anisotropy with depth through the interval from 500 to 800 mbsf. The cause of this effect is not clear.

Thermal conductivity data broadly follow the pattern of the porosity variation as may be expected, with some moderation by grain compositional effects. Interestingly there is no observable offset in the thermal conductivity curve at the décollement, where the porosity values are offset sharply. The significance of the conductivity data are that they provide a firm basis for the extrapolation of the 
observed shallow temperature measurements throughout the sediment column.

\section{Geochemistry}

Samples for both interstitial water analysis for inorganic chemistry, and headspace gas analysis for organic chemistry were taken systematically throughout the cored sequences. The inorganic chemistry dominantly responds to lithological signals of the formation chemistry and to potential perturbance of this signal by advection of fluids. Hence it can be a powerful indicator of hydrogeological effects. The organic chemistry responds to lithologic factors in terms of organic carbon content, but is primarily a function of biological activity, temperature, and time. In addition, possible effects may occur as a result of fluid flow. The complementary data from both aspects of the geochemistry will be reviewed in turn.

\section{Inorganic Geochemistry}

Effects observed in the inorganic analysis of pore-water chemistry can be broadly divided into four categories: biogenic effects mainly above 150 mbsf; lithologic effects controlled by the varying chemistry of the sedimentary sequence occurring at many lithological boundaries; diagenetic effects linked to either mineralogical changes or gas hydrate occurrences, mainly above $250 \mathrm{mbsf}$; and potential changes in concentration gradients due to fluid flow.

Biogenic effects are clearly evident in the concentration of dissolved sulfate, alkalinity, ammonia, and phosphate. Rapid changes in concentrations in the uppermost $20 \mathrm{~m}$ are mainly a product of the biological activity in this zone. Below this, biogenic methane production is linked with the changes in alkalinity and sulfate.

Lithologic boundaries are associated with signals in many chemical constituents, but major features are shown in the concentrations of calcium, magnesium, lithium, and silica. Changes in sodium, calcium, and magnesium occur in the upper $150 \mathrm{~m}$ and may reflect a combination of the biotic activity and diagenetic effects in that zone; there being close relationships between the two. There are subtle changes in chemistry at a depth of about 366 mbsf that clearly correlate with the frontal thrust (Fig. 85). A sharp variation in the lithium concentration curve typifies this chemical signature and is interpreted as a result of the juxtaposition of the different lithologies across the fault. The sharpness of this variation, with little apparent smoothing due to diffusion effects, argues that the fault motion is recent or indeed active. While this is in itself an expected conclusion, the presence of this anomaly also implies that the water chemistry is closely linked to the formations at this depth. This can be taken as evidence for little fluid circulation along the fault zone, which would probably have the effect of destroying this simple signature.

The boundary between the trench fill turbidites and the trench-basin transitional deposits at 560 mbsf produces major concentration changes in many components. Dissolved silica shows marked variability below this boundary, probably in response to the ash horizons present from this depth down to 820 mbsf (Fig. 88). Calcium, magnesium, and potassium also have abrupt concentration gradient changes at $560 \mathrm{mbsf}$, which can be related to diagenetic effects close to the lithologic boundary. The lithologic boundary at $824 \mathrm{mbsf}$ is marked only by relatively subtle changes, including a decrease in variability and absolute values of silica. There is no indication of any profound features either of lithologic contrast or fluid movement at this boundary. Below $1200 \mathrm{mbsf}$, changes in calcium, strontium, and the $\mathrm{Na} / \mathrm{Cl}$ ratio show a signal characteristic of alteration reactions occurring in the volcanogenic sediments overlying the basaltic basement.
A possible diagenetic front may be indicated at $195 \mathrm{mbsf}$ (Fig. 86). Here a sudden rise in silica, a local lithium maximum, a calcium increase and a magnesium decrease form a pattern comparable to that seen at other drilling sites (Gieskes et al, 1983). In each case a likely explanation of the effects involves alteration of volcanogenic material. Interestingly, these effects also coincide in depth with the depth of extinction of gas hydrates at this site. Another possible diagenetic signature at 560 mbsf has been described above.

Fluid flow effects can often be isolated by effects on the chloride concentration, because chloride is relatively unreactive in response to lithologic variations. A major chloride concentration anomaly exists (Fig. 82) with a minimum below the décollement (at about $1100 \mathrm{mbsf}$ ) rising slowly to reach a maximum at $560 \mathrm{mbsf}$. Though low chloride levels here have similarities to those found in the décollement zone of the Barbados Prism (Gieskes et al., 1990) where fluid flow was implied, at least some of the effect here can be attributed to in-situ reaction, perhaps by clay dehydration reactions at the ambient temperatures of $60^{\circ}$ to $120^{\circ} \mathrm{C}$. However, if low-chloride fluid flow has occurred, it probably would have been along the décollement. Such a lowchloride input would then have propagated to the sediments both above and below the décollement. This must have been a past event because the gradients observed are clearly diffusion affected. The possibility of a "leaky" décollement cannot be excluded, the leakage helping to maintain the chloride gradient. Evidence for fluid flow at other depths in the prism is weak or nonexistent.

\section{Organic Geochemistry}

Although a general decrease in sediment organic matter content occurs with increasing depth, marine organic matter appears to be abundant in all samples. Above 600 mbsf the low sulfate amounts coupled with significant methane abundance suggests bacterial origin of that methane. Gas components ethane to pentane (Fig. 104, Site 808 chapter) indicate that thermogenic gases appear below $380 \mathrm{mbsf}$, occur mixed with biogenic components to $1020 \mathrm{mbsf}$, and that below this depth only thermogenic gases are found.

The gas composition indicates that thermogenic gases from 600 to $800 \mathrm{mbsf}$ and 1060 to $1280 \mathrm{mbsf}$ were generated in-situ from the organic matter of the host sediments. This observation raises several important questions. The maturity of organic matter appears higher than expected from previously accepted models using heat-flow and temperature data. This may be the result of underestimates in these models. Also, the absence of gases within the zone 800 to 1060 mbsf remains enigmatic. Source organic material is definitely present. Either maturation temperatures were not reached, or the gases have been later removed. Both these alternatives would imply complex solutions. The existence of the décollement centrally within this anomalous zone may not be coincidental. However, there is no evidence for gas migration at the décollement level, or the frontal thrust. Resolution of this problem must await later analysis of the state of maturation of the organic carbon, and the isotopic composition of the hydrocarbon gases.

\section{Downhole Measurements}

While a large range of downhole measurements were attempted at Site 808 , problems with both the unstable hole conditions and the equipment reduced the range of useful data obtained. The measurements can be conveniently subdivided into two categories on a purely technical basis, wireline logging and discrete instrumental measurements. The former employs mainly Schlumberger well-logging technology, whereas the latter includes a wide variety of purpose-built tools. These measurements are central to the scientific objectives in providing direct 
measurement of in-situ physical properties and fields such as temperature, pore pressure and stress.

Wireline logging has a pivotal role in linking the recovered core material to the in-situ regime in the borehole. Despite considerable efforts, the logging activities met with very limited success, recovering only very limited sections of open-hole logs and being restricted to through-pipe logs for the interval from 0 to 750 mbsf. The causes of this were a combination of loose sands, swelling clays and rubbly fault zones, all of which made the holes highly unstable. It is tempting to speculate about the component of hole instability caused by break-outs due to tectonic stress effects, but no direct evidence was gained to indicate this might have been the case. The through-pipe logs require considerable correction for attenuation effects and their geological value has not yet been extracted.

The open-hole logs cover the depth ranges $80-180 \mathrm{mbsf}$ and 525-615 mbsf. Only in the lower interval was core recovery good. Here the log and laboratory average values for seismic velocity agree very closely, but the detailed correlation is only fair. In the upper logged interval the poor core recovery precludes detailed comparison. The log data do, however, show considerable lithological variability, reflecting the turbiditic nature of the sediments. Coarsening upward and fining upward cycles can be outlined from the natural gamma, resistivity, and sonic logs, the signal being largely a response to the varying porosity in the different turbidite units. The data also provide some definition of a porosity velocity relationship that may be useful for regional seismic velocity data. All possible log runs included the Lamont temperature tool (TLT) to record the borehole temperature profile. Despite the drilling disturbance, these data can provide useful constraints on equilibrium thermal profiles, and particularly on fluid flow. The data are discussed in the Heat Flow section below.

The success rate of instrumental downhole measurements was also not high. No useful data were obtained after repeated efforts with the rotatable packer, and the ONDO temperature tool was not successfully deployed on Leg 131. After some mechanical modification, the ONDO was successfully deployed on Leg 132, but as yet no measurements have been recovered from it. A vertical seismic profile experiment was limited by hole stability to the depth range 0-620 mbsf for the downhole geophones, and the noise level was high due to coupling of drill-pipe vibration into the casing. Nevertheless, detailed processing is expected to recover a useful velocity profile from these measurements. The newly developed lateral stress tool (LAST) was deployed seven times, recording data correctly on three of them. Owing to the loss of the nonmagnetic drill collar, the stress data cannot be orientated; however, magnitudes of in-situ horizontal stress and pore-pressure values are of great interest. Preliminary results from about $186 \mathrm{mbsf}$ (Fig. 151, LAST section, Site 808 chapter) indicate excess pore pressures exist even at shallow depths in the relatively coarse-grained turbidite sequence and that measured horizontal stress exceeds the vertical effective stress (at hydrostatic pressure). The water sampling, temperature, and pore-pressure tool (WSTP) was run several times in various holes within the depth range $0-390$ mbsf. Only five successful temperature determinations were made, and these are discussed in the heat-flow section below.

\section{Heat Flow}

Particular objectives of thermal properties were to establish the background advective heat flow at the site by determining the thermal profile and thermal conductivity values, and to assess the possibility of convective heat transfer. Thermal conductivity measurements were made routinely as part of the physical properties analysis and are described above.

Six reliable temperature measurements were made using the WSTP tool in the depth range 40 to 360 mbsf (Fig. 165 in Heat Flow section, Site 808 chapter). These values do not fall on a simple straight line, but are fit by a regression line giving a temperature gradient of $111^{\circ} \mathrm{C} / \mathrm{km}$. Unfortunately, for most of the depth range of these measurements, the core recovery was poor and the sediment disturbed, so that the thermal conductivity data are not very tightly constrained. Nevertheless, a heat-flow value of $126-129 \mathrm{~mW} / \mathrm{m}^{2}$ can be derived. Further thermal data from the downhole logs are quite compatible with this gradient, allowing for the complex effects of drilling circulation on the borehole thermal profile. The final temperature-depth predictions for the total depth range at Site 808 is shown on Figure 168 (Heat Flow section, Site 808 chapter). The value obtained is high, but within the range of that predicted purely from conductive heat transfer from oceanic crust having an age of that part of the Shikoku Basin $\left(125-136 \mathrm{~mW} / \mathrm{m}^{2}\right)$. Thus conduction is favored as the most significant heat transfer process through the sediments. It is possible that a lower predicted heat flow value should be considered to allow for the effect of the very high sedimentation rate in this area (Yamano et al., 1984). In this case the measured heat flow would suggest excess conductive flow of the same magnitude as the sedimentation rate correction.

None of the data reported here provide evidence for presentday fluid- flow activity at this site. The WSTP measurement at 299 mbsf could infer a $3^{\circ}-4^{\circ} \mathrm{C}$ negative anomaly at this depth, but experimental error in this value cannot be excluded.

\section{DISCUSSION}

\section{Sedimentary Facies Evolution}

The lithologies encountered at Site 808 can be interpreted in the tectonic context of Shikoku Basin evolution and dynamic stratigraphy of the Nankai Trough subduction zone. Here, we review the processes of facies evolution and regional history that provide a basis for understanding the structural evolution and hydrogeologic framework.

Opening of the Shikoku Basin emplaced basalts and basaltic tuffs. The basement lithology is similar to previous drilling sites in the Shikoku Basin (Leg 58, Sites 442, 443) and is composed of a lower pillow lava unit overlain by massive lava or sill units. The age (15-16 Ma) assigned by calcareous nannoplankton within the interbedded tuffaceous mudstone indicates that at least this portion of the oceanic basement is older than the age (14-12 Ma) inferred by the two-stage spreading episode proposed by Chamot-Rooke et al. (1987).

We hypothesize that the subduction of the active ridge caused anomalous near-trench volcanic activity, which formed acidic magma. This volcanic activity was a source for the pyroclastic deposits that were transported ca. $450 \mathrm{~km}$ to a position close to the ridge axis, explaining the lithology encountered in Unit V. Contemporaneous middle Miocene acidic igneous rocks exposed in the Kii Peninsula (Miyake, 1988) to the north of Site 808 may represent a part of this source region. This magmatism was succeeded by a longlasting rather quiet period of hemipelagic accumulation (14$2.5 \mathrm{Ma}$ ). Within this period there are some variations in sedimentation rate and lithology changes. Slow sediment accumulation below the décollement and a few peaks of $\mathrm{CaCO}_{3}$ input, highlight the variation. About $2.5 \mathrm{Ma}$, explosive volcanic activity started, enhanced probably in the southwest Japan-Ryukyu arcs, and ash layers started to accumulate. These ash deposits mark the transition from lithologic Subunit IVb to Subunit IVa. 


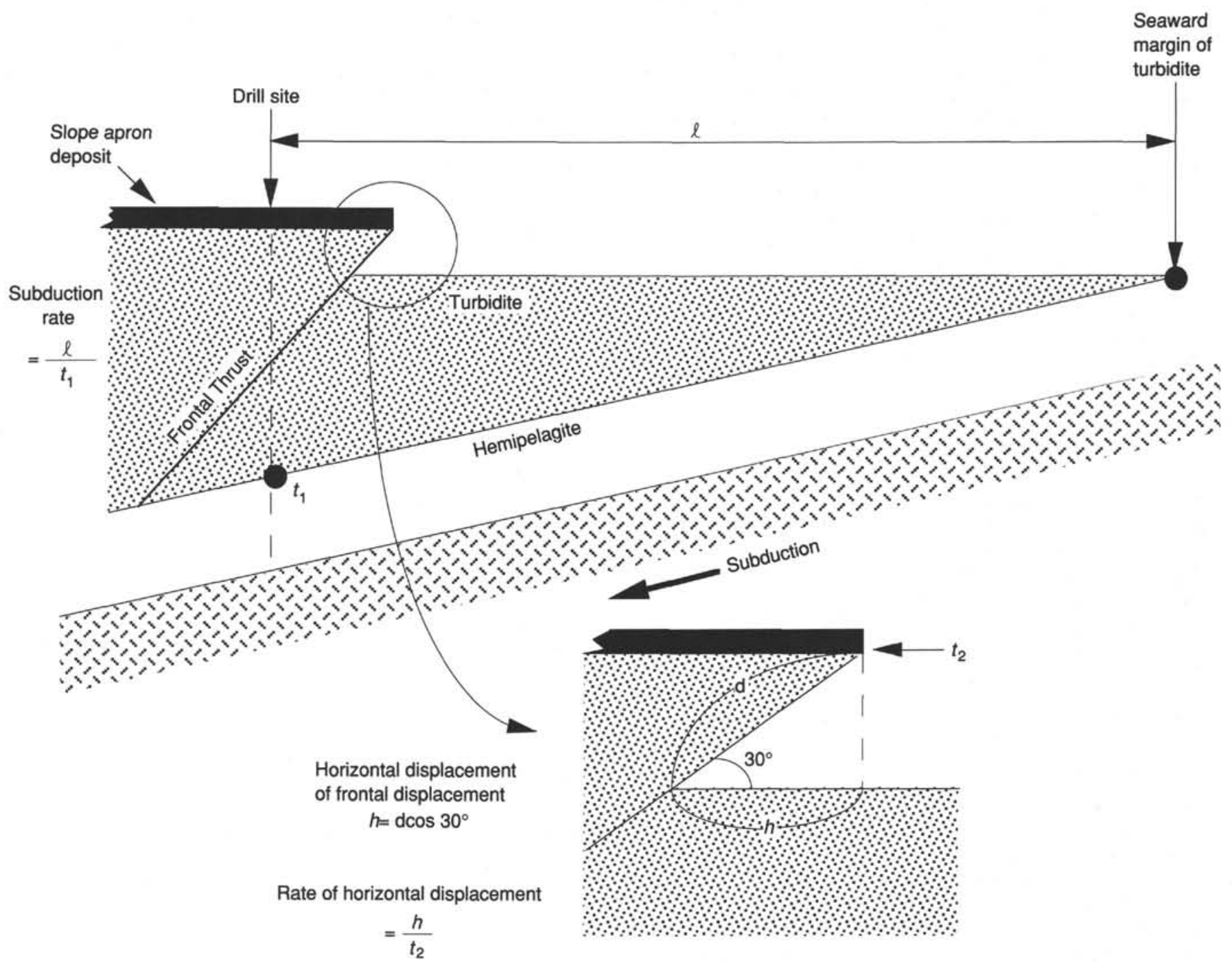

Figure 1. Diagram illustrating deduction of subduction rate and rate of thrust horizontal displacement.

About $0.5 \mathrm{Ma}$, more silt intercalation started in the deposits, brought by turbidity currents. The composition of silts is virtually the same as the axial trench facies, suggesting this unit was deposited at the trench outer high area of deposition. The paleocurrent measurements made on ripple cross-lamination suggest a dominant southeast-northwest direction, indicating a landward transport from the Shikoku Basin. This would require flow reflection off the outer trench slope and complex interaction between axial and transverse depositional systems. Unit III was overlain by a thick sequence of turbidites (Unit II) that accumulated in the trough. The sequence shows an overall coarsening upward cycle suggesting a progressive change from the outer trough margin overbank type environments to axial channel environments. Unit I can be interpreted as a sequence related to the development of the frontal thrust. Finer grain size and slump structures indicate a gradual elevation increase above the trench floor, and deposition was probably influenced by plumes of turbidity currents lapping onto the lower slope.

\section{Structural and Physical Property Evolution}

An interpretation of dynamic plate stratigraphy allows an estimate of the rate of subduction at the Nankai Trough, assuming the present trench width has been maintained (Fig. 1). The base of the trench wedge, Unit II, is $0.45 \mathrm{Ma}$. Because the distance between the drill site and the seaward margin of the trench fill is $15 \mathrm{~km}$, the convergence rate is about 3.5 $\mathrm{cm} / \mathrm{yr}$. The base of the trench wedge at Site 582 also gives a similar age of about $0.45 \mathrm{Ma}$. The distance from the trench margin to the site is $13 \mathrm{~km}$, which again provides an estimate of plate convergence of $3 \mathrm{~cm} / \mathrm{yr}$. These two independent estimates of the subduction rate suggest that, at least for the last half million years, the rate was 3 to $3.5 \mathrm{~cm} / \mathrm{yr}$, slightly slower than the instantaneous motion inferred from earthquake slip. If we assume perpendicular convergence and a constant convergence rate for the last $15 \mathrm{~m} . \mathrm{y}$., the basement of Site 808 was some $500 \mathrm{~km}$ away from its present position. If the origin of the acidic tuff is from a near-trench forearc region, the pyroclastic flows would have had to travel this great distance, suggesting a violent and voluminous nature of the volcanic activity.

Site 808 lithofacies also provide important insight into the movement of the frontal thrust. The age of the base of Unit I can be estimated by interpolation of the sedimentation rate, giving $0.02 \mathrm{Ma}$. We can refer to this as the initiation of thrust motion. The displacement along the thrust is estimated at 
about $300 \mathrm{~m}$ of dip-slip motion. The rate of fault movement is therefore $1.5 \mathrm{~cm} / \mathrm{yr}$. Assuming that the average angle of the thrust is 30 degrees, the rate of horizontal displacement of the fault is $1.3 \mathrm{~cm} / \mathrm{yr}$. This suggests that about $40 \%$ of the plate convergence is accommodated at the single frontal thrust.

The striking change in physical properties above and below the décollement is an important finding of this leg. A major increase in porosity from the accreted sediments to the underthrust sediments was found. Comparison of Site 808 sediment porosities with several consolidation curves of marine clastic sediment and with Site 582 indicates that the accreted sediment at Site 808 is probably overconsolidated and that underthrust sediment is underconsolidated. The underconsolidation condition of the underthrust sediment may be maintained by low matrix permeability and excess pore pressure. However, acoustic anisotropy increases normally with depth below the décollement, suggesting that the sediment has seen a normal consolidation pattern in the past.

These observations suggest the following consolidation history. At the Shikoku Basin side, hemipelagic mud accumulated with a slow accumulation rate where we expect a normal basin-type consolidation characteristic. It is likely that the normal consolidation trend imprinted on acoustic anisotropy was acquired at this time. At the trench, turbidite sedimentation took place at a high rate over $1000 \mathrm{~m} / \mathrm{m}$.y. This high sedimentation event could have induced an underconsolidated state in the hemipelagic sequence, although the sand and silt component of the turbidites provide high permeability pathways that may drain excess pressures. The controlling factor for the stratigraphic position of the décollement is not clear. Shi and Wang (1988) pointed out that high pore pressure is most likely to develop in the middle of a sedimentary section because of the maximum length of drainage pathway there. Although this general inference may be applied to the Nankai setting, the lithologic control of particular horizons is not clear. Two characters change across the décollement: the sedimentation rate and the peak in $\mathrm{CaCO}_{3}$ content. We are not sure whether these parameters are related to stratigraphic control on décollement development. Nevertheless, the sediments below and above the décollement have undergone very different consolidation histories. The underthrust sediment seems to remain underconsolidated, and parts of the accreted section may be overconsolidated.

\section{Hydrogeology}

There are several possibilities for the escape of fluid from the accreted sediments: (1) fluid loss occurs as pervasive upward diffusion through almost the entire accretionary prism; (2) fluid loss occurs in a semilocalized way, controlled by structures such as microfaults, shear bands, and clastic dikes; (3) fluid loss occurs in a localized manner through conduits such as the décollement, thrust faults, or certain stratigraphic horizons. Our shipboard results do not resolve this issue. However, there are several important observations.

Pervasive upward flow throughout the prism will affect numerous measurable parameters including heat flow and pore-water geochemistry. The thermal measurements at this site define raw thermal gradient and heat-flow values that are compatible with purely conductive heat transfer from the oceanic crust. A correction to account for the very high sedimentation rate in this area would lower the background heat-flow value probably by about $10 \%$, but with considerable range in error. This leaves open the possibility that the balance of the observed heat flow could be due to advection flow.

The geochemical data provide no clear evidence for pervasive fluid flow, while at the same time failing to completely exclude the possibility of such flow. For example, the $\mathrm{Cl}$ gradient can be attributed, at least in part, to in-situ clay diagenesis. The correspondence of pore-fluid geochemistry with lithologic boundaries argues that any flow must be slow, most geochemical gradients being determined mostly by reaction and diffusion.

The absence of a BSR at this site may also argue against considerable upward diffusive flow. If the BSR that is seen landward of this site is produced by upward diffuse flow as suggested by Davies et al. (1990), then the absence of a BSR at this site must again imply that any diffuse flow must be relatively slow or that the methane concentrations in the pore water are very different.

There is a clastic dike at $810 \mathrm{mbsf}$. Although we do not know the origin of the sand in the dike and when it was generated, it is reasonable to say that such dikes may be quite abundant within the prism. In the Shimanto Belt, Taira (1984) showed that sandstone dikes are quite common and were intruded into $30 \%-40 \%$ porosity mudstone. The present porosity value of the mudstone at this horizon is about $37 \%$ and possibly might have been intruded relatively recently after the deformation started. If so, this provides one important avenue of fluid expulsion.

Sidescan sonar seafloor images obtained by the IZANAGI system show the existence of sediment volcanoes in the trench floor of the Nankai Trough. Within the Kaiko-Nankai survey area of the eastern Nankai Trough there are several sediment diapirs. One was visited by the Nautile, but no recent fluid venting activity was detected. One swarm of volcanoes has been found at the Shionomisaki canyon fan, about $200 \mathrm{~km}$ east of this site. Another group is found $20 \mathrm{~km}$ southeast of this site. Three possible volcanoes with maximum diameter of $3 \mathrm{~km}$ are recognized near the deformation front. As we do not know the nature of these volcanoes, it is premature to further assess any importance of these features. However, it can be said that, although the number of sediment volcanoes is seemingly less than Barbados, at least they play some role in fluid expulsion in the Nankai Trough.

The complete absence of veining and mineralization was one of the surprising results of this leg. The absence of such veining even in the deformation zones, and the absence of any major geochemical signatures in the pore fluids, preclude the possibility of channelized fluid flow in this prism.

In the light of all the evidence, we conclude that the most likely mechanisms for fluid expulsion from the accreted sediments are: (1) upward diffusive flow through a large portion of the prism; and (2) rather localized material involved transfer processes such as diking and sediment diapirism. The role of the small faults and shear bands in fluid flow has not been ascertained.

The décollement was identified at 945-964 mbsf as a deformation zone below which the sediment is virtually undeformed (Fig. 2). This $20-\mathrm{m}$ zone of fractured rock offsets the porosity values from $30 \%$ above it to $40 \%$ below it, a huge difference over this narrow interval. The relatively coherent material from the décollement shows low porosity values (less than $30 \%$ ) and conjugate faults that record northwest-southeast shortening. Above the décollement, for about $100 \mathrm{~m}$, there is a concentration of faults that decrease in abundance upward. Therefore the physical properties are inhomogeneous in the décollement zone and the deformation is quite asymmetrical.

Two questions arise: (1) why doesn't the décollement transmit stress, and (2) how is the porosity difference maintained? These two issues may be inter-related. A simple assumption is that the décollement is a zone of lowest strength. If this is correct, the strength of material at this 


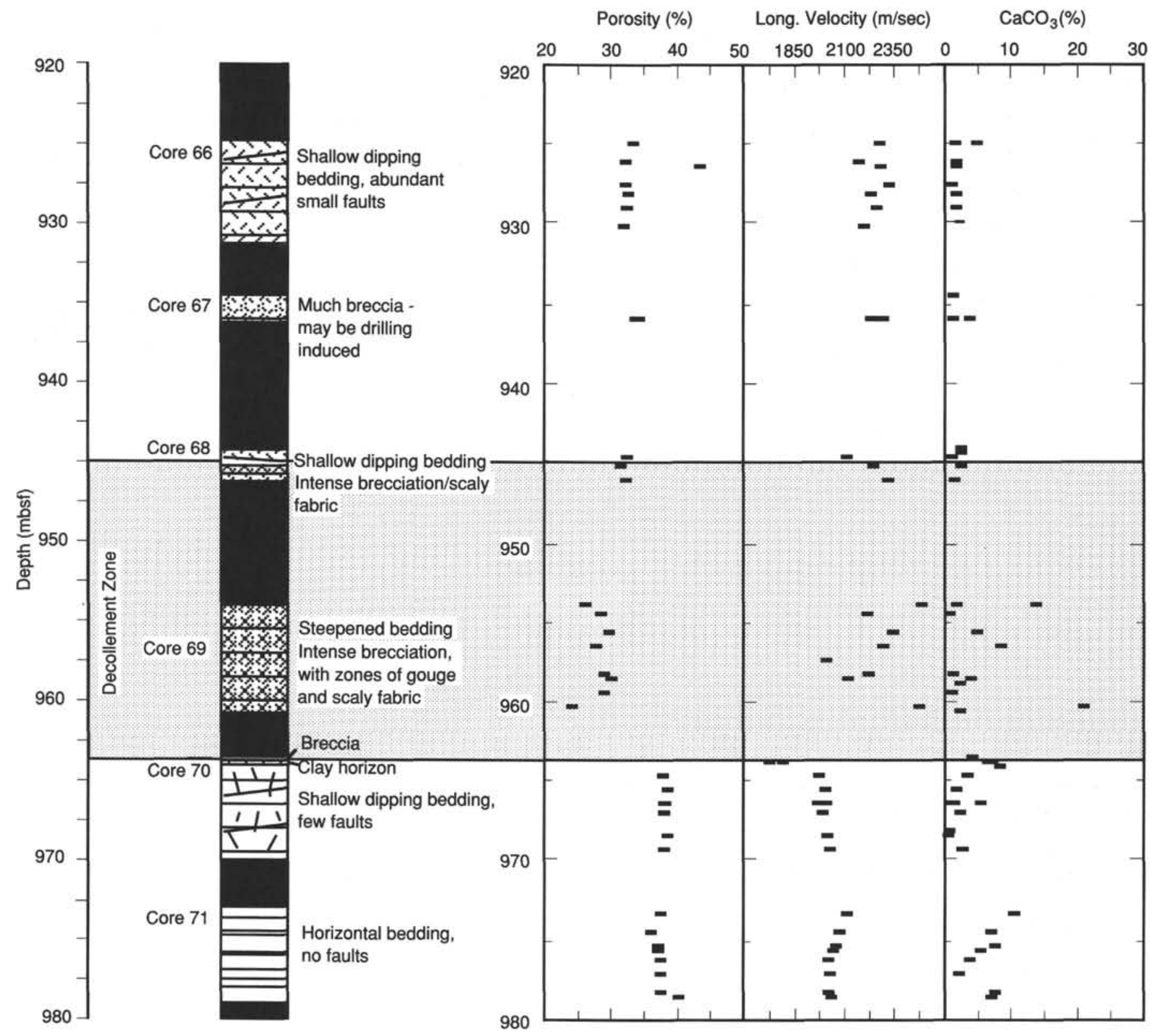

Figure 2. Core recovery, structural fabric, physical properties, and $\mathrm{CaCO}_{3}$ contact across the décollement.

depth has to be controlled by pore pressure, because we do not identify any variation in lithology or other parameters likely to influence strength. This leads to a view of the décollement as a zone of high pore pressure. However, the development of scaly fabrics and numerous fractures promotes the passage of fluid, and on this basis this zone should exhibit high permeability. These two requirements, the décollement as a zone of weakness and as a pore-pressure seal, lead to the conclusion that the décollement should be the zone of highest pore pressure in the section. If there is high fracture permeability, then abundant fluid flow would be required to maintain the excess pore pressure; however, no measure of the effective fracture permeability has been obtained.

The contention of abundant fluid flow is challenged by geochemical and mineralogical data that do not agree well with such a hypothesis. Evidence against this fluid-saturated décollement is that there are virtually no chemical/mineral precipitates or veins found at the décollement, and there are no obvious pore-water chemical anomalies or signatures of enhanced fluid flow.

One debatable exception is that of chloride. This chemical species shows a broad minimum near the décollement (the exact minimum lies $100 \mathrm{~m}$ below the décollement), which extends to nearly $1200 \mathrm{mbsf}$. As $\mathrm{Cl}$ is a quite inactive substance in the sediment pore water, we can consider the dilution of this to be a consequence of adding low $\mathrm{Cl}$ fluid to the system. Because such a broad trend of decrease can be considered as a diffusion-controlled process, the $\mathrm{Cl}$ minimums can be the consequence of injection of low- $\mathrm{Cl}$ fluid at the décollement from some time ago. Preliminary diffusion considerations yield a rough estimate that the injection occurred several hundred thousand $\mathrm{yr}$ ago. If the $\mathrm{Cl}$ signal is the evidence for large fluid flux at the décollement, why is there no other chemical species that shows some signature across the décollement? We suggest here that the evidence of the Leg 131 shipboard results may suggest a possible fluid-saturated 
décollement, likely to be episodic, but this inference is inconclusive.

The heat flow at this site is compatible with purely conductive heat transfer from the oceanic crust below. This does not preclude some component of advective transfer, perhaps compensated by the effect of very high sedimentation rates.

\section{CONCLUSION}

We list below some of the important findings, conclusions, and questions raised during the leg.

\section{Lithostratigraphy}

Provenance of sands was confirmed as similar to Site 582 , mainly from the Suruga Trough drainage system. An overal coarsening-upward trend in trench sedimentary facies was clearly defined. A complex pattern of turbidity current activity, however, was found in the outer trench environments. This suggests a sequence of events such as slumping and turbidity current generation from the prism, and transverse to oblique reflection of flows off the seaward slopes. The mineralogy of detrital grains such as quartz/feldspar shows grain-size-dependent features representing coarsening upward sequences. There is an acid pyroclastic horizon just above the basaltic basement rocks suggestive of near- trench forearc volcanism at 15-14 Ma. Basement lithology of basalts indicates upper sill layers above a pillowed horizon similar to the Leg 58 results.

Around 800 mbsf there is a clear peak in zeolite mineralization. As the lower boundary of the peak shows such an abrupt termination, it is a lithology-controlled (ash abundance) change. There is a slight increase in illite content and asymmetry of the illite $(001)$ peak, and a concomitant decrease in smectite content between 550 to $800 \mathrm{~m}$ suggestive of clay dehydration.

\section{Structural Geology and Physical Properties}

Physical properties analysis indicates three main zones of property changes, these being above, within, and below the décollement. Downhole changes of physical properties generally show normal consolidation patterns, although portions of the offscraped sequence appear to be relatively overand underconsolidated. Sediments within the décollement are highly overcompacted, and underlying subducted sediments are underconsolidated relative to their lithologic equivalents above the décollement. Thus, the décollement marks a significant offset of physical properties. The lower zone shows an acoustic anisotropy that is indicative of a normal consolidation history. Pore pressure and in-situ stress was only measured in the uppermost offscraped sediments, but preliminary results indicate that excess pore pressures and high lateral stresses exist even at these relatively shallow depths.

Structural geology shows evidence of northwest-southeast shortening above the décollement and virtually no deformation below. Among prominent structural features, shear bands are confined to the upper $600 \mathrm{~m}$ and seem to have formed earlier than the small faults, both structures reflecting bulk shortening of the prism. We conclude that the stress field throughout the prism has a maximum horizontal compressive stress oriented northwest-southeast. Below the décollement the principal stress is vertical. Thus the décollement acts as a zone of very low strength isolating the different stress regimes.

\section{Hydrogeology}

Organic geochemistry indicates two different stratigraphic horizons of thermal generation of hydrocarbons, at 600-800 mbsf and 1050-1200 mbsf.
Inorganic geochemistry of pore fluids suggests there are four important processes operating in this prism: (1) Nearsurface decomposition of organic materials; (2) diagenetic effects (and possibly gas hydrate generation); (3) equilibration to lithologic compositions; (4) possible fluid injection. This latter process is of fundamental importance to the evolution of the prism. A broad $\mathrm{Cl}$ minimum in the lower part of the section may indicate a possible fluid injection along the décollement. However, the great width of this feature is surprising. It may have been generated, at least in part, by dehydration reactions of clay minerals. If the $\mathrm{Cl}$ minimum was created by fluid injection, consideration of diffusion rates suggests that this must have occurred at least several hundred thousand yr ago. In the light of our failure to observe any unequivocal evidence for localized fluid flow, we conclude that diffuse flow probably dominates the hydrogeologic pattern of this prism.

These findings can be condensed into two important conclusions for sediment deformation processes at this convergent margin.

1. The prism is undergoing localized thrust displacement and significant bulk shortening, but is decoupled from the undeformed sediments below.

2. Although inconclusive, hydrogeologic inference suggests the possibility of a fluid-saturated, highly pressured décollement. The accreted sediments above, however, seem to have drained by diffuse flow and some material transfer such as diking and diapirism.

Shore-based studies should provide further insight into the problems and inferences outlined above.

\section{REFERENCES}

Aoki, Y., Kinoshita, H., and Kagami, H., 1986. Evidence of a low-velocity layer beneath the accretionary prism of the Nankai Trough; inference from a synthetic sonic log. In Kagami, H., Karig, D. E., Coulbourn, W., et al., Init. Repts. DSDP, 87: Washington (U.S. Govt. Printing Office), 727-735.

Aoki, Y., Tamano, T., and Kato, S., 1982. Detailed structure of the Nankai Trough from migrated seismic sections. In Watkins, J., and Drake, C. L. (Eds.), Studies in Continental Margin Geology. AAPG Mem., 34:309-322.

Bray, C. J., and Karig, D. E., 1986. Physical properties of sediments from the Nankai Trough, Deep Sea Drilling Project Leg 87A, Sites 582 and 583. In Kagami, H., Karig, D. E., Coulbourn, W. C., et al., Init. Repts., DSDP, 87: Washington (U.S. Govt. Printing Office), 827-842.

Chamley, H., Cadet, J. P., and Charvet, J., 1986. Nankai Trough and Japan Trench Late Cenozoic paleoenvironments deduced from clay mineralogy data. In Kagami, H., Karig, D. E., Coulbourn, W. C., et al., Init. Repts. DSDP, 87: Washington (U.S. Govt. Printing Office), 633-642.

Chamot-Rooke, N., Renard, V., and Le Pichon, X., 1987. Magnetic anomalies in the Shikoku Basin: a new interpretation. Earth Planet. Sci. Lett., 83: 214-228.

Davies, E. E., Hyndman, R. D., and Villinger, H., 1990. Rates of fluid expulsion across the northern Cascadia accretionary prism: constraints from new heat flow and multichannel seismic reflection data. J. Geophys. Res., 95:8869-8889.

Gieskes, J. M., Vrolijk, P., and Blanc, G., 1990. Hydrogeochemistry of the Northern Barbados Accretionary Complex Transect: ODP Leg 110. J. Geophys. Res., 95:8809-8818.

Gieskes, J. M., Elderfield, H., and Nevsky, B., 1983. Interstitial water studies, Leg 65. In Lewis, B.R.T., Robinson, P., et al., Init. Repts. DSDP, 65: Washington (U.S. Govt. Printing Office), 441-449. 
Kaiko I Research Group, 1986. Taira, A., and Tokuyama, H. (Eds.), Topography and Structure of Trenches Around Japan-Data Atlas of Franco-Japanese Kaiko Project, Phase I: Tokyo (Univ. of Tokyo Press).

Kato, S., Sato, T., and Sakurai, M., 1983. Multi-channel seismic reflection survey in the Nankai, Suruga and Sagami Troughs. Rept. Hydrographic Res., 18:1-23.

Kobayashi, K., and Nakada, M., 1978. Magnetic anomalies and tectonic evolution of the Shikoku inter-arc basin. J. Phys. Earth, 26:391-402.

Leggett, J. K., McKerrow, W. S., and Casey, D. M., 1982. The anatomy of a Lower Paleozoic accretionary forearc: the Southern Uplands of Scotland. In Leggett, J. K. (Ed.), Trench-Forearc Geology. Geol. Soc. Spec. Publ. London, 10:496-520.

Miyake, Y., 1988. Petrology of the Shionomisaki igneous complex, southwest Japan and its implication for the ophiolite generation. Mod. Geol., 12:283-302.

Moore, G. F., Shipley, T. H., Stoffa, P. L., Karig, D. E., Taira, A., Kuramoto, H., Tokuyama, and Suyehiro, K., 1990. Structure of the Nankai Trough accretionary zone from multichannel seismic reflection data. J. Geophys. Res., 95:8753-8765.

Nasu, N., et al., 1982. Multi-channel Seismic Reflection Data across Nankai Trough. IPOD-Japan Basic Data Series, 4. Ocean Res. Inst., Univ. of Tokyo.

Niitsuma, N., 1988. Neogene tectonic evolution of Southwest Japan. Mod. Geol., 12:497-532.

Okuda, Y., and Honza, E., 1988. Tectonic evolution of the Seinan (SW) Japan fore-arc and accretion in the Nankai Trough. Mod. Geol., 12:411-434.

Shi, Y., and Wang, C.-Y., 1988. Generation of high pore pressures in accretionary prisms: inferences from the Barbados Subduction Complex. J. Geophys. Res., 93:8893-8909.

Shih, T. C., 1980. Magnetic lineations in the Shikoku Basin. In Klein, G. deVries, and Kobayashi, K., et al., Init. Rept. DSDP, 58: Washington (U.S. Govt. Printing Office), 783-788.
Shimamura, K., 1988. Sedimentation and tectonics of Zenisu Ridge, Eastern Nankai Trough and Suruga Trough Regions. Sci. Rep. Tohoku Univ., Ser. 2, 58:107-167.

Shiono, K., 1988. Seismicity of the SW Japan arc - subduction of the young Shikoku Basin. Mod. Geol., 12:449-464.

Shipboard Scientific Party, 1986. Site 582. In Kagami, H., Karig, D. E., Coulbourn, W. C., et al., Init. Repts. DSDP, 87: Washington (U.S. Govt. Printing Office), 35-122.

Stoffa, P. C., Wood, W. T., Shipley, T. H., Bothelo, H.A.B., Taira, A., Tokuyama, H., Nishiyama, E., Suyehiro, K., and Moore, G. F., in press. High resolution expanding spread and split-spread marine seismic profiles: Acquisition and velocity analysis methods. J. Geophys. Res., 95:8753-8765.

Taira, A., 1984. Tectonics significance of sandstone dykes in the Eocene Murotohanto Group, Shimanto Belt (subduction complex), Shikoku. Res. Rept. of Kochi Univ., 32:162-178.

Taira, A., Katto, J., Tashiro, M., Okamura, M., and Kodama, K., 1988. The Shimanto Belt in Shikoku, Japan: evolution of Cretaceous to Miocene accretionary prism. Mod. Geol., 12:5-46.

Taira, A., and Niitsuma, N., 1986. Turbidite sedimentation in the Nankai Trough as interpreted from magnetic fabric, grain size, and detrital modal analyses. In Kagami, H., Karig, D. E., Coulbourn, W. C., et al., Init. Repts. DSDP, 87: Washington (U.S. Govt. Printing Office), 611-632.

Taira, A., and the Scientific Members of the Expedition, 1988. Preliminary Report of the Hakuho-Maru Cruise KH86-5. Ocean Res. Inst., Univ. of Tokyo.

Taira, A., Tokuyama, H., and Soh, W., 1989. Accretion tectonics and evolution of Japan. In Ben-Avraham, Z. (Ed.), The Evolution of Pacific Ocean Margins: Oxford (Oxford Univ. Press), 100-123.

Yamano, M., Honda, S., and Uyeda, S., 1984. Nankai Trough: a hot trench? Mar. Geophys. Res., 6:187-203.

\section{Ms 131A-107}

